Before continuing with his investigation, Wiesing examines the theory of normativity and concludes that one cannot speak of just one "ethic of responsibility", but that one has to speak of different concepts of ethics of responsibility in which the notion of responsibility plays an important role. He presents a brief overview of the theories of responsibility of Weber, Weischedel, Picht, Schwartländer, Jonas and Lenk, and examines these different approaches towards the notion of responsibility. Wiesing argues that a number of strands of the philosophical discussion of responsibility cannot be applied to the activities of the physician, especially ontological positions. Responsibility does not demand a predetermined action, but an engagement in reflecting about possible actions in order to accomplish those tasks which cannot be solved, if stringent duties are adopted.

The physician - in his or her relation with the patient - has a threefold responsibility: first, an explicit mode of behaviour, such as non-maleficence, confidentiality, the duty to disclose, and respect for the autonomy of the patient. These modes of conduct can easily be identified at the theoretical level, but in practice they are dependent on the situation. Second, the physician is obliged to act according to the current state of the art and third, despite the uncertainty of the outcome, he or she is obliged to act conscientiously. These three levels are all necessary and not interchangeable. Furthermore the responsibility of the physician should be limited in that the patient must be the primary concern of the physician; social considerations should not influence or interfere with this relationship.

These traditional responsibilities of physicians apply equally to modern medicine. In cases such as euthanasia, abortion or gene therapy, society has the responsibility to decide, whether these means should be implemented, but physicians have the responsibility to determine how they should be implemented.

Wiesing's book is well and consistently structured and written with great clarity. It makes comprehensible and intelligible reading even for the non-philosopher, and would be useful for those interested in their role as physicians.

ECKHARD HERYCH

Zentrum für Ethik und Recht in der Medizin, University of Freiburg,

Germany

\section{Bringing the Hospital Home: Ethical and Social Implications of High-tech Home Care}

Edited by John D Arras, Baltimore, Johns Hopkins University Press, 1995,250 pages plus index, $£ 33.00$

"Home is the place where, when you have to go there./They have to take you in". So said Robert Frost, the outstanding American poet and his view still prevails, though the cost of the exercise has only recently been appreciated. There is a strong belief in the UK that in America they do things differently but that in due course the same events appear here. If this be so there are grounds for considerable anxiety, for two strands, one technical, the other managerial, have joined to produce a frightening prospect. For example, the use of central lines to administer total parenteral nutrition and systemic antibiotics has made it possible for those who, a short while ago, would have had a tenuous existence in a sophisticated hospital, to come home and for the care of the line to be delegated to nurses and relatives. Again, miniaturisation of complex technology has reduced the enormity of the iron lung to a suitcase pack. Secondly, the changes in medical management have led to a "sicker and quicker" approach to discharge by hospital managers demanding rapid turnover of beds in order to obtain maximal funding.

In 1992 a group began a study of the issues delineated in the title of this volume. Sixteen papers represent their opinions on a wide variety of topics, from children to geriatrics, from terminal cancer to lifetime support, from psychological, social and ethical issues to the problems of high-technology, from the moral to the economic. That the group managed to produce so splendid a text in so short a time leads one to think that there had been much previous heart-searching; indeed the depth of the approach speaks profoundly of the pain that has been experienced by these carers, both professional and lay. Perhaps the most startling part of the text comes from the specific American experience of health care. There the high-tech providers appear to be promoting market forces - a frank exploitation among the sick and dying to a degree that demands Senate investigation. British doctors have learned to their cost in the last few years that the National Health Service (NHS) is not immune to market forces and the demand for high-tech medicine is likely to be as strong here as over there.

This being so it behoves us to study the American experience in the light of our own particular situation. Each person in the UK has a personal physician who is able, if not always willing, to visit at home, and in this area there has long been an interchange between the local hospice and the home in the care of the terminally ill. Again, many local areas have had the good sense to maintain the war memorial cottage hospital, albeit updated as a community hospital, for conditions requiring less than the full blown high-tech approach. Staffed by GPs these serve a locality, providing respite care which enables carers to obtain relief from the constant burden of care. Finally, the primary health care team centred on the health centre provides a focus for care between the major hospital and the home. The importance of these features is apparent in view of the American situation where there appears to be no halfway house between the major high-tech institution and the home. Area mante agers would do well to think hard? before closing that inefficient, oldfashioned, ex-workhouse, horrid though it may well be in the light of the stainless steel and flashing diodes of the major centre, for people live and die at the periphery as well as expeditiously in intensive care. Unless it be that with thoughts of their own mortality they rebuild at the periphery, as Oxfordshire has so well achieved.

The immorality of the early discharge and the arrival of high-tech demands on the family are well illustrated by case studies, one of which demonstrates clearly the cruelty of forcing an untrained wife to manage, 24 hours a day, seven days a week, a respirator that is her husband's sole lifeline, waiting day and night for the bleep that indicates a mechanical - or worse an electronic - failure that she is untrained to manage. If the marriage be a good one it will be stretched to cope, if it be average it is severely at risk. Much of the problem arises from the belief that if there is an answer to a problem then the answer must be supplied - life at any cost. Whilst this approach may be right in the relatively young it cannot sensibly be applied to the elderly or the terminally ill. There the requirement is for the best 
obtainable death not a marathon of misery, a high-tech horror story.

This is an important text, worthy of study by both the medical team and the managers. Absorb the detail before concluding it couldn't happen here, for it so easily could. Managerial choice is rarely seen as involving an ethical decision, and if it is then unexamined utilitarian principles rule. It is ironic that Frost's words "take you in" can carry the scent of a con-trick - to be taken in - though con-tricks only work when the victim thinks he or she is getting a better than expected deal. Let us not be conned: high-tech home care, a streamlined parachute? This excellent text will serve its purpose if we stop and consider before mounting the rollercoaster of high-tech home care.

GORDON LENNOX

General practitioner

\section{Ethical Aspects of Human Reproduction}

Edited by Claude Sureau and Francoise Shenfield, Paris, John Libbey Eurotext Paris, 377 pages, $160 \mathrm{FF}$

This book of proceedings and papers was published following the FIGO symposium on ethics in reproductive medicine and biology held in Paris in 1994. As half the papers are written in English and half in French, it is not the easiest of books to delve into: papers are written primarily in one language and then summarised in the other. However, the careful editing and natural overlap between presenters allows for adequate coverage of all the major ethical problems encountered by clinicians in reproductive medicine.

Clearly divided into sessions, topics included are research on pre-embryos; the use of fetal tissue for transplantation; sex selection; surrogacy, and the practice of female genital mutilation. Debates and discussions between contributors following each paper raise interesting issues from different parts of the globe.

Malcolm Macnaughton's clear account of surrogacy and gamete donation in the UK is excellent, explaining the differences following the Surrogacy Act of 1985 and the HFEA Act of 1990, the latter clarifying the legal status of the child and donor. The papers on the use of fetal tissue for transplantation attempt to explore the ethical minefield surrounding this area. The question of "when does life begin" is explored, and hence when fetal tissue can be obtained. One author suggests that since the fetus cannot perceive pain until 20-22 weeks, then it would seem reasonable to retrieve tissue only before this gestation. A set of guidelines are offered that should ensure that the decision to abort is kept separate from the decision to use fetal tissue. The section on female genital mutilation is interesting, pointing out that this affects 100 million women worldwide. While there appears to be clear consensus that mutilating operations on unconsenting children are abhorrent, the question of whether re-infibulation following childbirth is unethical is rather different. Although the Royal College of Obstetrics and Gynaecology has favoured a ban on re-infibulation, one author feels that this operation on a consenting adult is an entirely different issue and that it is possible to favour such an operation without necessarily condoning the practice of genital mutilation in the first place.

This concise book is of value to all of us working in the field of reproductive medicine, where ethical dilemmas are faced regularly, as well as those interested in medical ethics. It does not attempt to provide answers but succeeds in stimulating discussion and, as such, is a useful addition to any bookshelf.

LESLEY REGAN
Department of Obstetrics and
Gynaecology, Imperial College School of
Medicine at St Mary's, Norfolk Place,
London W2 $1 P G$

\section{Books: information and orders}

If you wish to order or require further information regarding the titles reviewed here, please write to or telephone the BMJ Bookshop, PO Box 295, London WC1H 9JR. TelO 0171383 6244. Fax: 01713836662 Books are supplied post free in the UK and for BFPO addresses: Overseas customers should add 15 per cent for postage and packing. Payment can be made by cheque in sterling drawn on a UK bank or by credit card (Mastercard, Visa, or American Express, stating card number, expiry date, and full name (The price and availability are occasionally subject to revision by the publishers). 